\title{
Forming Legislation: Pluralism Between Adat Law and State Law
}

\author{
Tunggul Anshari \\ Faculty of Law \\ Brawijaya University \\ Malang, Indonesia \\ tunggul@ub.ac.id
}

\begin{abstract}
This article provides a discussion material concerning position of adat law in the process of forming positive law seen from the perspective of legal pluralism. The main issue focused on this article is to what extent, from the perspective of theories, adat law can be accommodated into a positive state law through the process of legal acculturation and assimilation. This article concludes that the fruitfulness of the making of positive law, taking, borrowing, or adopting adat law, will heavily rely on the capabilities of the parties involved to understand general principles, equality, and differences among legal systems.
\end{abstract}

\section{Keywords - adat law, positive law, legal pluralism}

\section{INTRODUCTION}

The space for democracy established by the 1945 Constitution of the Republic of Indonesia (UUD NRI 1945) has triggered the existence of adat-based revival that reflects cultural and traditional aspects. Both foreign and local experts have shared similar thoughts that revivalism is triggered by political, legal, social, cultural, and economic factors that are closely related to one another especially after the downfall of the new order regime. In terms of law, it can be identified according to the agenda of legal structure reform from centralism to decentralism which allows communities to participate in the governance for almost all aspects. The form of infiltration of the revival can be seen from existing legal products such as sharia-based regional regulation or regional regulation that accommodates the elements of local adat culture, or the Law Number 12 of 2011 concerning Formation of Legislation. At a national level, the adat community movement such as the Alliance of Adat Law Community (AMAN) has pushed the government and the House of Representatives to immediately complete Bill on Recognition and Protection for adat law people although it does not reflect the expectation of the community. Law Number 6 of 2014 also gives a new colour to the adat law-related issue, as it brings the role of the adat community to the fore in the making of adat regulation. However, not a few people in academic environment and societies share similar thought that anything related to adat is always irrelevant. They refuse that the traditional boundaries among societies are getting more vague. Apart from all those debates, this issue is often inserted to the context of the quest of typical tradition of law in Indonesia that is still going on[1], [2]. This quest is also known and called as volksgeist by Savignian.
Such a polemic can also be seen in theoretical scope of legislation. The debate between universalists and particular group regarding the position of legal standing in a positive law of a state has existed since Dutch East Indies, which only represents small part of the major problems in law of a state[3]-[5] ${ }^{1}$. The most common term commonly found in literature of the northern country is globalised law, transnationalised law, and borderless sovereignty, illustrating the transformation of legislative practices which are marked by legal transplantation[6] ${ }^{2}$ defined as adoption of law commonly occurring in the legislative process that runs the governance, judicature body, and commerce. This phenomenon creates adat law that exists among societies especially in southern states where adat law is still relatively dominant - no longer receives trust concerning its capacity in solving national issues. Southern countries especially Indonesia, do not have alternative choice but to reform legal structure that is directed to liberalism and modernism as requirement to receive foreign aid. In other words, practices of adat law that has been sublimed into societies will soon be identified as an impeding process instead of being seen as part of law modernisation.

This paper offers a brief discussion based on theoretical aspect concerning the position of adat law in a law-making process according to the perspective of legal pluralism. Instead of the dichotomy of written law (lex scripta) vis-a-vis

The debate between universalists led by Van der Puute and particularists led by Scholten van Oud Haarlem to determine the adat law as a law recognised by colonial state in a colonialised state. Since the dispute, there has been a strong awareness that what has been known as adatrecht really exists and this adat concept is not a normative precedent compilation written as the concept of law of Rome-Germanic used by the Dutch. In the independence, the debate between groups of traditionalists standing against communists and radical nationalists in the process of the making of Law Number 5 of 1960 on Agrarian Basic Principles also repeats the similar substance of the debate. In short, the adat law that is negotiated in regard to the making of Law is the law that ..... feudal and colonial elements

2 The term legal transplantation started to be developed by the movement of studies of law of development in the US and UK to understand universal symptoms of legal transplantation based on western law occurring in underdeveloped countries. The concept of legal transplantation refers the application of a law that comes from western countries to a state and social structure that are brand new. Tim Lindsey defines transplantation as The adoption of a particular model seeking to achieve the same result as that produced by the original model. This process is often described as modernization or westernization. The reason for doing this are numerous and changing: colonialism, imperialism, post-colonialism, democratization, perceptions of modernity and progress. and economic decline or collapse 
unwritten law (lex non scripta), graduates of law faculty who still follow socio-legal method-as what is maintained in this article - are more focused on theoretical implication from the position of adat law by carefully observing the formation of law that takes, borrows, or implements a concept of adat law brought to the product of positive law that is made. The formation of good legislation is certainly based on how firm is the legislation toward adat law that expresses legal awareness of the locals. Although this issue is not quite new to discuss or run in legislative practices, as long as the author has observed, there has not been any discussion done based on theoretical perspective with socio-legal dimension.

\section{DISCUSSION}

\section{A. Adat law: Conceptual Definition}

It goes without saying that the term 'adat law', part of it, was certainly influenced by the tradition of Dutch civil law. Adat law based on literature - either the one written by local or overseas graduates - always refers to a legal framework that stems from traditional culture that never stops growing and developing, following social process in the societies[7]. Conceptually, the problem encountered regarding the identification of adat law does not merely lie on problematic definition of 'adat law', but to figure out whether adat customs deserve to be called adat law. This question has been raised for quite a long time. For example, Dust East Indies bachelors like Snouck Hurgronje and Van vollenhoven defined in two, as a legal manifestation and as a habit. As a legal manifestation called adatrecht, an adat is taken as an interactive product between adat authority and particular adat community that has sanction levels. ${ }^{3}$ On the other way around, an adat can be defined as merely a custom when it is related to ongoing activities of individuals in the societies, and this custom is passed through generations. Although this notion is welcomed by bachelors in Indonesia, they add that what determines adat as a law or not must be based on the notion of the communities concerning the law per se.[8] Supomo, for example, asserts that adat law is a living law, as it represents the obvious soul of law from its people[9]. This perspective theoretically emphasises moral and ethic imperative which serve as the fundamental in forming legal framework.

Despite the fact that moral and ethic imperative can be traced through Pancasila and the 1945 Constitution of the Republic of Indonesia, the adat law, surprisingly, encounters existential problem when the state has no more choice but to keep colonial legal framework that is settled as a foundation of a new life just to prevent any absence of law[10] ${ }^{4}$. Similarly, Asia, Africa, and Latin America also face such a problem. In politics, this is linked to effort to gain political support from societies concerning the newly born state. The growing political decolonisation also triggers national elites

Positivists often criticise that adat law does not deserve to be called as a law simply because it is not a product from government that is codified and has binding force. The charactieristic of adat law delivered verbally ha made adat law keep changing from time to time depending on who interprets and is dominant in the societies. This results in the absence of legal certainty.

The statement regarding the effectiveness of colonial law can be found in the 1945 Constitution of The Republic of Indonesia Transitional Regulation Article II stating: all state bodies and existing regulations are still into effect as long as no new regulations according to this Constitution. to immediately leave adat law regarded as an old tool that is irrelevant to development. Along the history of modern Indonesia, this practice is commonly performed by the state in spite of the fact that it is quite dilemmatic for local bachelors[11] . From the perspective of the state[12]:

[S]uch different treatment is basically a logical consequence of the state's need to promote its own political agenda, so the response given to non-state laws has always been measured against the benefits to the state as well as the level of their bargaining position in relation with the state itself. This shows that the extent to which the state is willing to respond positively to the implement-tation of non-state laws depends greatly on the challenge posed by the latter.

As the time goes on, the paradigm that positions state law as the only accepted law cannot give solution to the problems occurring in societies. The socio-legal bachelors of law faculty, for example, criticise that this pragmatic approach brings destructive consequence where not all are treated the same by state law. Centralism paradigm of western law which keeps being forced in its process of legislation does not always bring expected results, as they opine that such a positive legal product is not in line with the perspective that grows among the interactions of the societies.

\section{B. Considering Paradigm of Legal Pluralism in Law- making Process}

Bachelors of Law following socio-legal method believe that adoption of foreign law in a positive law legislation is aggressively defined as a process of directing people to submissive mode toward adat law that has been passed through generations, even before this state was born. Obviously, it can be seen from almost all aspect of legal aspects such as in land-related administration, governance, judicature, inheritance, and marriage. For example, presenting proof concerning ownership right of land by means of ipso jure adopted from western culture does not fulfil the validity of proof according to ipso facto which is usually found in adat law ${ }^{6}$. Moreover, politics in court unification performed in several countries in postcolonialism has caused the uniformity of mechanism needed in dispute settlement which does not always bring merit and not relevant to the expectation of the locals.

Therefor, the bachelors of law in socio-legal field offers alternative paradigm of legal pluralism that is aimed to remanage the structure of national law - including in legislation - by being involved in variety of legal systems under the same social fields[13] $]^{7}$. There are two concepts of legal pluralism: (1) weak legal pluralism and (2) strong legal

As an example of adat court (inheemse rechtspraak) regarded by national elites as irrelevant to the concept development of the Unitary State of the Republic of Indonesia. Court unification has begun since 1951 with Emergency Law Number 1 of 1951 concerning Temporary Action to perform a unity of structure of power and court procedure civil court till 1966

6 Adopting the concept of ipso jure is seen common in the third world countries. This process is actually related to the need of strategic need of countries of development through foreign investment that requires land in large proportion. However, in reality, the conflict between westernised land law and adat land law often results in the loss of rights to land, embedded to the adat law, either collectively or individually

John Griffiths further elaborates the definition of legal pluralism as 'the deviant situation which state law recognizes some body of customary law.' p. 9 
pluralism[14]. The first concept assumes that a state law still prioritises every issue occurring in societies although the adat law still functions. This concept offers a perspective in which a state still holds its sovereignty to highlight its authority and to control all social groups[14]. On the other hand, the latter concept assumes a fact that not all laws are regarded as state law that is managed in autonomy by an authorised party. The law not included in positive law is known to have authoritative power to control social behaviours of the societies and there is always alternative to settle disputes according to the existing legal systems.

Those who are in favour of this paradigm attempt to define the complexity of normative regulation in the social structure, in which it holds merit theoretically to give understanding why a certain legal product is not effective in settling a dispute. As Ratna Lukito argues, the absence of effectiveness of a certain positive legal product also depends on the narrow way of thinking of the formation of law and state that is only focused on legal issues. In the practice, such a tendency triggers the existence of legal instrumentalism where a state excludes the tradition of adat law not relevant to what is supposedly needed. This can be seen in human resource. This exclusion causes dysfunction of a system of adat law resulting in the loss of rights and freedom of an individual who follows that regulation[15]. This triggers to asymmetry of access to the rights of the citizens that are guaranteed by the constitution.

The paradigm of legal pluralism tries to take out the inherent exclusion of legal instrumentalism through the interaction between tradition of western positive law, and the tradition of adat law enables accommodation and adoption between traditions to happen (this has been performed in several states including Indonesia)[12]. Interaction between legal traditions could result in hybrid law - a combination of several different legal systems[16]. According to those following legal pluralism, an attempt to borrow a legal format from different law does not necessarily mean abiding behaviour, but it could be a strategy for a law to survive. When the law gets stronger, it will be more possible for the law to be complementary and exists next to other laws. Therefore, the alternative to formalise adat law into positive law is more regarded as a strategy to keep legal pluralism[17].

In the process of forming the law as what will be discussed further, the key to maintaining legal pluralism depends on the process of positive law making where a regulation can be negotiated by other related parties discovering general principles seen based on the prospect of social change in societies.

\section{From Legal Centralism to Legal Acculturation and Legal Assimilation}

Legal centralism is a logical consequence of a legislation process that prioritise legal instrumentalism paradigm. This paradigm provides a chance for a state to monopolise the process of forming a law that also triggers a view that a law should also be performed by formal state apparatuses while the law not included in state organisation (religious and adat law) is overlooked because its existence is not accepted[8]. There is sometimes a resistance due to the limited law of a state to tolerate the existence of adat law. To solve the problem, bachelosrs of socio-legal propose a concept of legal acculturation and assimilation aimed to integrate adat law and modern law (western law) into a particular legal document.

Firstly, legal acculturation is an attempt to integrate two ore more legal traditions by selecting relevant elements. The aim of such a legal acculturation is to reduce the substantive gap between modern law and adat law. In an objective situation, the state (at the moment) admits two legal traditions and simultaneously structures an agenda that composes the two into a positive legal document that applies nationally $[18]^{8}$. There is nothing more dominant in the two legal traditions mentioned because which level of traditions is influential relies on the social perspective toward each tradition. The level of the state's role is also derived from the two which are quite determining in becoming facilitators for the process of law making whose essence does not determine the direction of the legal substance being formulated. This process not only requires the procedure in the formation of legislation that is democratic, but it is also focused on cognitive ability of legislators or societies that are participating in the process to understand which elements are considered appropriate.

Secondly, the legal assimilation means compromising all tradition of law that exists to create a new law that declaratively exempts citizens from abiding a particular legal system $^{9}$. This strategy is achieved when a state is incapable of settling a conflict sparked between legal traditions and when a state fails to achieve legal uniformity model. As expressed by Ratna Lukito, legal assimilation is the main method that is mostly taken by legislators to reduce any conflict in law[12]. However, to what extent a conflict can be reduced or even eliminated depends on the capability of legislators to find general terms of legal traditions that are against each other.

\section{CONCLUSION}

The formation of a positive law that takes, borrow, or implements a concept of adat law into the mid of positive law of a state, either through legal acculturation or assimilation is determined by to what extent parties are involved in the process to understand general principles, similarity and difference in legal system. Despite the fact that a country has such an intention to create a new positive legal product based on adat law, the effectiveness and whether the law is accepted by societies heavily rely on how wide the scope of the product is when it is linked to the values of life of the societies. To achieve the objective, legal pluralism approach can be used in law-making process to link two irrelevant legal systems.

\footnotetext{
As an example, concept regarding the land ownership for peasants as stated in Basic Agrarian Law (UUPA) is basically adopted from the concept of land ownership that grew in Javanese societies. In addition, social function of land in Law also reflects collective lifestyle of villages in Java, referred to as general principles regarding the use of a land. The adoption of this notion applicable at national level is obviously linked to the agrarian political agenda of a state that sees that the perspective of adat law is in line with the demand of peasants concerning the takeover of excessive lands, acceleration of agricultural industries and intention to gain political supports at grass root level

9 An example of legal assimilation can be seen from Law Number 1 of 1974 on Marriage that integrates three traditions of law: western, adat, and Islam simultaneously. This legal product reflects the ability of a state to assimilate varied tradition of marriage into legal product applied nationally.
} 


\section{REFERENCES}

[1] J. Davidson and D. Henlye, The Revival of Tradition in Indonesian Politics the Deployement of Adat from Colonialism to Indigenism. Oxon: Routledge, 2013.

[2] A. D. Tyson, Decentralisation and Adat Revivalism in Indonesia the Politics of Becoming Indigenous. Oxon: Routledge, 2010.

[3] P. Burns, The Leiden Legacy Concepts of Law in Indonesia. Jakarta: Pradnya Parmita, 1995.

[4] J. F. Holleman, Van Vollenhoven on Indonesian Adat Law. Leiden: KITLV, 1981.

[5] G. G. Siong, "Law Reform in Indonesia," J. Comp. Int. Priv. Law 26 Jahrg H. 3, 1961.

[6] T. Lindsey, Ed., Law Reform in Developing and Transnational States. London: Routledge, 2007.

[7] M. Koesnoe, Hukum Adat sebagai Suatu Model Hukum Bagian I (Historis). Bandung: Mandar Maju, 1992.

[8] R. Lukito, Tradisi Hukum Indonesia. Jakarta: The Institute for Migrant Right Press, 2013.

[9] Soepomo, Bab-bab tentang Hukum Adat. Jakarta: PT Pradnya Paramita, 2003.

[10] S. Wignjosoebroto, Dari Hukum Kolonial ke Hukum Nasional.
Jakarta: KITLV, 2010.

[11] D. S. Lev, "Unifikasi Pengadilan Pada Masa Pasca-Kolonial," in Hukum dan Politik di Indonesia, Jakarta: LP3ES, 2013, p. 228.

[12] R. Lukito, Legal Pluralism in Indonesia Bridging the Unbridgeable. Oxon: Routledge, 2013.

[13] J. Griffiths, "What is Legal Pluralism," J. Leg. Plur., vol. 32, no. 24, p. 12, 1986.

[14] S. A. Jackson, "Legal Pluralism and the Nationa State: Romantic Medievalism or Pragmatic Modernity?," Univ. Michigan J., p. 2.

[15] R. Simarmata, Pluralisme Hukum dan Isu-Isu yang Menyertainya. Paper HuMa.

[16] M. A. Safitri and T. Moeliono, "Bernegara Hukum dan Berbagai Kuasa dalam Urusan Agraria di Indonesia: Sebuah Pengantar," in Hukum Agraria dan Masyarakat di Indonesia Studi tentang tanah, Kekayaan Alam dan Ruang di Masa Kolonial dan Desentralisasi, Jakarta: Publisher HuMa, Van Vollenhoven Institute and KITLV, 2010, p. 13.

[17] R. H. Perdana and B. Steny, "R Herlambang Perdana dan Bernandinus Steny," in Pluralisme Interdisipliner Sebuah Pendekatan Interdisiplin, T. HuMa, Ed. Jakarta: Publisher Rumah Kemasan, 2013, p. 431.

[18] N. F. RAchman, "The Resurgence of Landreform Policy and Agrarian Movement in Indonesia," University of California, 2011. 